\title{
Organizing Against Concessions
}

\section{Toni Gilpin}

\author{
Yale University
}

What the newspapers have dubbed "concessions bargaining," and what many union activists now call "stickup negotiations," began in Detroit. In 1979, the Chyrsler Corporation, facing bankruptcy, claimed that extensive contract concessions from the United Auto Workers were necessary in order to keep the company solvent. Threatened by the spectre of plant closings and layoffs if the contract was not re-opened, the UAW agreed that Chrysler workers would give up, among other things, $\$ 3$ an hour over the next three years. Yet the plant closings and the layoffs were not forestalled. The Chrysler workforce stood at 100,000 in 1979; it is now less than 46,000. The company will soon have closed, permanently, two-thirds of its plants in Detroit. The city's official unemployment rate is approaching 20 per cent.

Detroit was thus a particularly appropriate location for the Labor Notes conference last November devoted to "Organizing Against Concessions." Labor Notes, a monthly newsletter which keeps track of insurgent rank and file activity in the union movement, has watched the concessions demands spread from Chrysler to the other auto makers into other industries, as ailing companies and prosperous corporations alike have insisted that the unions they deal with give up scheduled wage increases, pension and vacation benefits, and "costly" work rules-or else. The three-day "Organizing Against Concessions" conference drew together union activists who are trying to combat this new management strategy. Among the most vocal and the most angry delegates at the conference were UAW members who work, or once worked, at Chrysler plants in Detroit.

The turnout for the conference was impressive-some 760 people attended. I was one of only a handful of academic types at the conference, and one of the few people not to have a local union number on my nametag. Auto workers, UE members, and Steelworkers were particularly evident; public employees, Machinists, and members of the Teamsters for a Democratic Union seemed present in large numbers as well. In all, members of 48 national and international unions attended the conference, from 25 states and the District of Columbia and from Canada, Ireland, and England. Alejandro Molina Lara, former secretary-general of the Fishing Industry Union in El Salvador, addressed the delegates, along with keynote speaker Jean-Claude Parrot, president of the Canadian Union of Postal Workers, who had spent two months in jail for leading his union on strike in 1978 . 
Many of the grievers, the organizers, and the local presidents at the conference stand in active opposition to the policies their own unions' national leaderships have pursued in the face of the concessions movement.

The conference agenda was divided between four main sessions, when all delegates came together to hear speakers, and some 22 workshops devoted to more specific issues. One of the major problems with the workshops consisted of choosing which to attend: topics ranged from "Unemployed Organizing," to "Quality of Work Life," to "Researching the Boss' Finances;" meetings by union or industry and by geographic area were also somehow fit into the schedule. Conference participants consistently emphasized two clear sentiments: a conviction that union concessions do not save jobs, and an opposition to the conciliatory approach which much of labor's top leadership has adopted in response to this latest employer offensive. As Parrot emphasized in his address, " . . . if the labor movment adopts concessions, embraces profitability, and does nothing to maintain workers' rights, then it becomes another instrument which merely mediates the repression of workers." This, however, was about where the general consensus ended - no monolithic solution was agreed to; no resolutions were offered. Both the featured speakers and delegates in the workshops expressed difference of opinion about workers' correct response to giveback demands and proposed varying new directions for the labor movement. Some of the union members present would have preferred some more specificity, I think, particularly in the workshops, to help direct them in their immediate struggles with management. The lack of a "bottom line," however, promoted the open discussion that proved one of the conference's strong points.

Bob Weismann, president of UAW Local 122, advocated a position reminiscent of John L. Lewis when he pledged "No Backward Step" for his mine workers. $\mathrm{He}$ attacked the "ivory tower intellectuals" who believe that concessions demands present new opportunities for the labor movement. People are kidding themselves, Weismann argued, if they think that workers are getting a fair exchange when they trade wages and benefits for promises of input into company affairs. Management will not give up any real power over the bargaining table, he argued, and those who seek equal sacrifices from management are buying the companies' argument that concessions are necessary in the first place. As the president of a UAW local, and a Chrysler one at that, he acknowledged that simply saying no to concessions demands would not guarantee union victories. Nevertheless, Weismann received a standing ovation, and particularly loud cheers from some UAW members, for his hard-line approach. Don Tormey, a UE organizer, also castigated management's "briefcase stormtroopers" who expect to placate unions with stock option plans, profit sharing, or quality of work life programs.

Yet some speakers did emphasize the possibility that a new role for American labor could emerge out of the concessions battle. Tony Mazzocchi, former vicepresident of the Oil, Chemical, and Atomic Workers' Union, has inaugurated a "Campaign for Corporate Concessions" in an attempt to call into question traditional labor-mangement relations. In his speech to the conference, Mazzocchi argued, "Our collective bargaining agreements said in writing that management has 
the unilateral right to manage. The perimeters of bargaining were defined. It is time to change those assumptions." Mazzocchi and other unionists stressed that workers should not give up wages and benefits that they had already won unless they receive a guarantee of real input into company policies-particularly those concerning investments, capital movement, plant closings, and the introduction of new technology. Without such decision-making power, workers battling multinational corporations will not be able to ensure either their contractual gains or their continued employment.

Along with these varying analyses of labor's current problems, the main speakers advocated different strategies aimed at revitalizing American trade unionism. Representatives from public and service employees unions, in particular, maintained that new alliances must be forged to fight against concessions. Rich Gibson, from the Michigan Employees Association, and Reg McGhee, an international representative for the American Federation of State, County, and Municipal Employees, stressed the common interest of public employees and their constituencies: reductions in the staffs of welfare and unemployment offices, educational agencies, and health and safety programs throw public employees out of work and hinder the ability of those who remain on the job to serve their clients. Public sector unions, in this era of Reaganomics, can play an important part in building new coalitions between labor and the community. Many speakers also recognized the need for active cooperation between the employed and the unemployed, for without such efforts people desperate for any job at all are not likely to sympathize with union members who struggle to protect decent wages and benefits. Members of the Mon Valley Unemployed Committee from Pennsylvania, along with some two dozen other local unemployed organizations, decided at the conference to establish a national network and information clearinghouse.

There was, of course, much talk of the need for larger solutions to the problems concessions bargaining represents. Several speakers emphasized the need for a labor party; many also stressed the importance of increased international working class solidarity. At the workshops on "Understanding the Economic Crisis," participants argued that the corporations' call for concessions underscores the serious nature of capitalism's current crisis. The ensuing debate was a familiar one-whether or not it is possible to achieve real reform without social revolution. Many, perhaps most, of the trade unionists at the conference agreed that socialism in some form or fashion is desirable; they certainly did not demonstrate any particular reluctance to use the term. Yet for those workers currently engaged in concessions negotiations, or for those threatened with a plant closing, calls for sweeping change might be stirring, but not completely satisfactory. The conference delegates seemed especially interested in hearing the experiences of their fellow workers' local fights against concessions, to determine what immediate strategies they might utilize to win their own battles.

Many of the stories exchanged at the conference were grim. Workers' personal accounts revealed the widespread impact of the concessions campaign, and its cost in human terms. Georgia Ellis, a 14-year UAW member from Elmwood, 
Indiana, told of her bitter struggle with United Technologies. Ellis was one of 89 employees of UT's Essex Wire subsidiary, where 85 per cent of her co-workers were women and about a third of them were close to retirement. Early in 1982, the company lawyers called for a meeting with the plant's bargaining committee and asked what the employees would give up to keep the plant open. The workers, who earned \$4.31 an hour, said they could not afford to give up anything. Some three weeks later, without further warning from the company, Georgia Ellis went home from the night shift at $7 \mathrm{a} . \mathrm{m}$. to read in the morning paper that the plant would close that day at noon-for good. Essex Wire's workers received no severance pay and no insurance from United Technologies, the 12th largest employer in the country. Ellis was tearful but undeterred as she told the conference her story. She and other members of the "fighting grannies," as the Essex Wire women dubbed themselves, now spend time driving to picket lines in Indiana to lend support to other workers battling concessions.

Some people at the conference told stories of more well-known struggles. Rick Long, formerly an air traffic controller, discussed the 1981 Professional Air Traffic Controllers' Organization strike, and the fate of the 11,400 controllers fired by President Reagan. After the strike was broken and the union decimated by the federal government, about 200 PATCO members, many of whom are Vietnam veterans, took jobs outside the United States. Long said that none of the expatriated controllers he had talked to have any desire to return to this country.

Most of the reports, whether from small plants or huge corporations, were equally somber, but there were a few success stories to relate. One of the most dramatic was the UE's battle against Morse Cutting Tool in New Bedford, Massachusetts; local union officials discussed this strike at a workshop detailing case studies of resistance to concessions. Morse, owned by Gulf and Western, demanded a $51 \mathrm{c}$ an hour wage reduction and other benefit concessions from its 650 employees in April, 1982, threatening to close the plant if the workers did not give in. The UE local, however, did not conceed but went on the attack, charging Gulf and Western with "milking the cash cow," channelling profits out of the plant to other areas of the Gulf and Western empire. The union maintained that capital investments, not pay cuts, would save the plant, and they enlisted considerable support from state senators and representatives, city councillors, church and community groups and other local unions, which formed a Citizens' Committee to Support the Morse Strikers. The most surprising assist probably came from the local police, for the Police Union strongly supported the strike. The walkout lasted thirteen weeks, and in the end the UE claimed victory. Although the Morse workers will not receive a pay raise for two years, no wage cuts were imposed, and the contract contained modest increases in pension and insurance benefits. Most significantly for the community, the plant will not close-at least not in the immediate future. The Morse workers at the conference stressed the community's involvement in the strike and the union's research into the company's finances, as the central elements that contributed to their victory.

The PATCO strike, of course, and to a lesser degree the Morse victory, were relatively familiar stories. Yet much of what was discussed at the conference, partic- 
ularly in the halls over drinks or hot dogs, had not appeared in the popular press, even in newspapers or journals sympathetic to labor. These conversations reminded me, as a historian, of the inadequacy of consulting only the official press to determine the mood and momentum of the labor movement. Since I have an ongoing interest in the Auto Workers, I was especially struck by how much I learned about developments within the UAW that I have not seen reported elsewhere. The restless UAW members at the conference, bitter about the positions taken by their union's top leadership, pointed to aspects of the concessions contracts which have not received much general attention. For the first time, for example, I heard the actual language of the strike ballot that U.S. Chrysler workers voted on after they overwhelmingly rejected the company's contract offer last October. It read:

Select only one option:

1. Since Chrysler Corporation says that it is unwilling and unable to grant an immediate wage increase at this time, we should recess negotiations until immediately after the Christmas holidays, when hopefully the nation's economy will have improved. In the interim we would continue to work under the agreement which was in effect prior to September 14, 1982.

2. Strike the Chrysler Corporation at 10 a.m. Monday, November 1, 1982.

Doug Fraser and the UAW Executive Board thus made it clear that they were "unwilling and unable" to lead a strike, and consequently the fact that 70 per cent of the U.S. Chrysler workers who voted selected option 1 does not seem terribly surprising. The Canadian UAW leadership was not, however, willing to wait until after Christmas to force a better offer out of Chrysler, and their 10,000 members went on strike on November 5 . The Canadian strike compelled Fraser and Chrysler management to re-open negotiations before the New Year. The hat was passed at the conference to raise money for the strikers; the delegates contributed $\$ 1,355$ to demonstrate support for the Canadian action.

The battles going on inside the shops because of new concessions contracts are also going largely unreported. I met Carole Travis, a GM worker from Illinois currently on lay-off, at the conference; her father and mine had worked together in the early days of CIO organizing in Chicago and Detroit. She explained to me the absentee control program inaugurated by the latest GM contract (a similar plan is contained in the new U.S. Chrysler contract as well). The program tallies employee absences - excused and unexcused-during a six month period. If a worker has been absent for more than five days during the six months, he or she can be subject to punishments including disciplinary layoffs and discharge. Decisions on such action are made by a committee of two management and two union officials; their judgements are non-grievable and supercede all other plant attendance procedures. The UAW top leadership backed such a program for GM and Chrysler, arguing that chronic absenteeism increases the company's costs while reducing efficiency and quality. It is not, of course, a new concept for the UAW to assist in disciplining the 
workforce, but the absentee control programs seem particularly insidious.

"Organizing Against Concessions" provided me with a solid sense of the extent and the implications of management's new offensive, but it offered no historical context for the understanding of this current information. While the delegates caucused in workshops for their particular unions, the handful of labor educators at the conference met together as well. Few of the 22 people who assembled for this meeting were labor historians per se; most were involved in labor education programs, focusing on popular economics and politics. The role of history in workingclass education was not originally on the agenda for the workshop. A young Canadian union member with an interest in labor studies thought that perhaps it should be. He and some friends, he said, had been discussing at breakfast the need for a 30 hour week, and what strategies unions might utilize to fight for it. "Then someone asked how we even got the $\mathbf{4 0}$ hour week," he said, "and nobody knew."

The conference in general devoted little specific attention to the past triumphs of the labor movement or to the precedents for the current concessions crisis. The most genuinely historic analysis I heard, in fact, came not from American unionists but from two Irish labor leaders from the Derry Trades Council. They invoked the names of Larkin and Connolly (and Engels) not simply for rhetorical flourish, but because, it seemed, they thought that historic references were necessary in their assessment of the present situation in Ireland. When the American unionists utilized history at all, it was often employed in a somewhat inconsistent fashion. I heard some UAW dissidents, for example, condemning their union's current national leadership for being too conciliatory with the bosses and too manipulative of the rank and file. "We need a leader like Walter Reuther again," one of them said; the rest agreed. Yet it was Reuther, calling for new methods of labor-management cooperation, who helped introduce the five-year no-strike contract and the notion of tying workers' wages to profitability-schemes which now reveal their flaws as companies demand contract re-openers and profitability plummets. Much of the membership's knowledge about their union's history, of course, comes from official UAW accounts, where questions concerning the wisdom of Reuther's decisions are not likely to be encouraged. One young UAW member from New Jersey told me that he was disappointed to discover, only recently, that Reuther had done a little redbaiting in his lifetime. A lot of redbaiting, I told him. He seemed even more disappointed.

This conference renewed my conviction that workers must understand labor's past in order to map out new strategies for the union movement-but it also underscored how little historical assessment is going on within the ranks. Union activists, it seems, are not quite convinced that such retrospective scrutiny is necessary, or perhaps they do not see it as the best place to devote their energies. And labor historians, unfortunately, have not yet proved to be much help on this front. The labor educators at the conference that I spoke with complained that the trade unionists they work with find much of the "new" labor history, when they read it at all, inaccessible and dull. As this conference drew to a conclusion, I began to wish 
that more historians had been present. Somehow or another, we have to establish ways to connect the work that we do to the work that is going on within the centers of activism in the labor movement. 